\title{
Individual health related applied activity in special health group girl- students' way of life in the process of their studying
}

\author{
Bartnovskay L.A. ${ }^{1}$, Kudryavtsev M.D. ${ }^{1,2,3,5}$, Kravchenko V.M. ${ }^{1}$, Osipov A.Yu. ${ }^{2,4}$, Baranovskaya L.A. ${ }^{3}$, Ignatova V. V. ${ }^{3}$ \\ ${ }^{1}$ Krasnoyarsk State Pedagogical University named after V.P. Astafyev, Russia \\ ${ }^{2}$ Siberian Federal University, Russia \\ ${ }^{3}$ Reshetnev Siberian State University of Science and Technology, Russia \\ ${ }^{4}$ Professor V.F. Voino-Yasenetsky Krasnoyarsk State Medical University, Russia \\ ${ }^{5}$ The Siberian Law Institute of the Ministry of Internal Affair of Russia, Russia
}

\begin{abstract}
Purpose:

to find out actual life style of special health group girl students in context of their individual health strengthening and improvement, as well as to assess their demands in physical culture practicing.

Material: $\quad$ as the object of the research we determined different kinds of leisure and day regime of girl students with weak health $(n=300)$. We analyzed the structure of personality's leisure time: reading, creative work, participation in social life, cultural progress of personality, time expenses for health values.

Results: $\quad$ we have found that girl students have insignificant demand in individual health related applied activity. We note noticeable minority of girl students, practicing physical culture often. The regime of educational work is a reason of girl students' asthenic state.

Conclusions: The received data witness about absence of constructive girl students' efforts, directed at health improvement. Independently girl students do not show physical activity oriented on health improvement. Day regime will be real and feasible, if it is flexible and considers unexpected circumstances.

Keywords: questioning, girl students, special health group, leisure activities, life activity, recreation, day regime, physical culture.
\end{abstract}

\section{Introduction}

Studying at higher educational establishment requires from students intensive intellectual, emotional and physical tension. It renders significant impact on their health, which is a pre-condition of future self-realization, ability for further studying and for professional activity.

Research of special health group's girl students' value orientations in advance is very important. It is necessary to maintain their healthy life activity [21] in real conditions of educational process with compulsory physical culture application [31]. This, most important kind of human activity, is of great significance in girl students' system of values.

At present, in foreign researches especial significance of not admittance of any dangers in mastering future profession is noted. It is necessary to exclude dangerous uncertainties in gaining knowledge [4], illogical competences in the field of education [5], in professional training of specialists [6]. Besides, it is necessary to use the experience of teachers in students' teaching to health protection and physical culture [28].

In HEE educational process it is necessary to envisage technologies for reduction of harmful habits' proliferation [18], reduce probability of internet addiction's progressing [19], computer games addiction [20], cultivate students' habits to healthy life style [10] and formation of healthy life style [9].

Studying in modern HEE to large extent is based on application of computer information technologies. For success in education students shall correctly organize their life activity. Regime of work and leisure shall ensure their (c) Bartnovskay L.A., Kudryavtsev M.D., Kravchenko V.M., Osipov A.Yu., Baranovskaya L.A., Ignatova V. V., 2017 doi:10.15561/18189172.2017.0502 sound health [27]. It is very important to plan the kinds of leisure activities. Leisure time shall ensure use for health, basing on sufficient physical activity [8]. Leisure time shall be devoted to physical exercises [2] and sports activity since adolescents' age [3].

Spending free time for "rest” with computer, students can loose not only health. They can loose potential for successful studying and for success in future professional activity.

In this connection, it is very important to study the problems of students' health preservation, i.e. creation of educational technologies, which would exclude students' immobility [12] and influence positively on their physical and psychic health [30].

Foreign scientists found disturbing tendency to excessive weight [23], obesity progressing [25], absence of physical activity and drawbacks in physical fitness of adolescents [11] and students. Especially important is to consider gender and physical distinctions of different age categories of rising generation [24]

This tendency permits for the authors of this article to agree with sad conclusions of domestic and foreign specialists about insufficient effectiveness of most standard programs of students' physical education [10]. It is necessary to orient on successfulness of general and special qualities' training at different stages of students' education [7].

Analysis of scientific works in the field of health protection, medicine, sports and physical education permits to affirm that there is noticeable weakening of physical condition and health of most of modern young people. The main threats for students' health are immobile way of life [27] and obesity [25]. Modern scientific works 
of scientists, dealing with students' health protection shall be devoted just to elimination of these global threats [26].

Hypothesis: the authors assumed that transition of Russian education to positions of modern education shall be regarded as organized process of healthy personality's teaching. In this aspect the system of modern education contains the following elements: variability of educational programs, priority of human values, free development of personality, ensuring of personality's self determination, creation of conditions for personality's self realization. For this purpose it is necessary to analyze the forms of students' leisure. Besides, it is necessary to estimate the demands in physical culture practicing, regime of work (rest, eating and sleep) for working out and further realization of measures on organization of health related students' education.

The purpose of the research is to find out actual life style of special health group girl students in context of their individual health strengthening and improvement, as well as to assess their demands in physical culture practicing.

\section{Material and methods:}

Participants: in the frames of experimental work, at initial stage we fulfilled written questioning of special health group (SHG) girl students $(n=300$, age 17-19 years) of $1^{\text {st }}-2^{\text {nd }}$ year of pedagogical HEE (girl students with health problems).

Organization of the research: we tested girl students of Krasnoyarsk State Pedagogical University named after V.P. Astafyev (KSPU). It is explained by the fact that their actual life style in conditions of educational process to large extent influences on girl students' health.

The relevance of girl students' health preservation problem is conditioned by specific of social demographic group. Due to different reasons physical and psychic health of young people cause reduction of their culturalsport activity. For determination of girl students' actual way of life we conducted research, consisting of three stages.

At first stage we determined the direction of the research. We worked out the project of pedagogic experiment (September-October 2016), selected and tested the methodic of the research.

In compliance with the purpose of the research the following tasks were defined:

1. Specify conception "health", its meaningful characteristics; criteria; indicators of individual health and healthy life style.

2. Find out how girl students understand "healthy life style"? which its features characterize girl students' life activity?

3. Clear up, how girl students understand importance of physical culture practicing for health preservation.

4. Find out girl students' attitude to attending bars, cafes, and so on.

5. Study significance of leisure activities for healthy life style formation.

6. Work out the questions for questionnaires:
1. Structure of SHG girl students' leisure.

2. Day regime of SHG girl students.

7. Analyze girl students' activities in the process of mastering knowledge.

For solution of the mentioned tasks, in OctoberNovember 2016 we questioned 300 SHG girl students of $1^{\text {st- }} 2^{\text {nd }}$ years.

Second stage (October-November 2016). Girl students questioning was fulfilled. During questioning the content of questionnaire was corrected.

Third stage (December 2016 - March 2017). Analysis of results was conducted, as well as their mathematical statistic processing, generalization and analysis of objective information; conclusions were specified.

Statistical analysis: we found, calculated and analyzed the following girl students' percentages: hobbies in leisure time; real picture of their activities in leisure time; their ideas about their preferences in leisure activities, day regime.

Mathematical-statistic processing of girl students' questioning results was used for assessment of the received data. As a result numerical material was determined in the following way (proportion): $\mathrm{A} / \mathrm{B}=\mathrm{M} / \mathrm{N}$. We found the main attribute of proportion $\mathrm{A} * \mathrm{~N}=\mathrm{B} * \mathrm{M}$.

$\mathrm{N}=\mathrm{B} * \mathrm{M} / \mathrm{A}$,

Where $\mathrm{N}$ - is unknown multiplier, $\mathrm{B}-100, \mathrm{M}-$ known multiplier, A - known multiplier.

Statistical analysis of leisure and day regime structure is given in tables 1 and 2 .

\section{Results}

Questioning results showed undoubted priority of meetings and walks with friends in the structure of SHG girl students' leisure $(91.3 \%$ - constantly and often). Naturally, communication with peers is characteristic for social-psychological characteristic of young people. A little lower is passive leisure - listening o modern music (78.82\%); the third lace is taken by watching TV and video records (53.9\%). Special health group girl students of pedagogic HEE like reading fiction $(34.6 \%$ - often); newspapers and magazines (31.7\% - often). Studying of special literature engages constantly $34.6 \%$ girl students; often $-25.0 \%$, from time to time $-36.5 \%$, and practically no girl students - 4\%. A little part of girl students (28\%) devote free time to social life and $41.3 \%$ do not participate in it. Girl students often attend disco and bars (22.1\%).

Priorities in leisure sphere are an important indicator of young man general culture. Unfortunately, for the questioned girl students it is not connected with physical culture: $71.1 \%$ of girl students practice physical culture from time to time. $34 \%$ - practically do not practice physical culture.

Physical culture is a kind of human motor functioning. However, in everyday life most of the questioned girl students $(36.5 \%)$ pay little attention to organized and independent physical culture trainings, sports and hiking. $34.6 \%$ of girl students practically do no physical exercises. Only for $28.9 \%$ of girl students, physical culture is an integral part of leisure. 
Table 1. The structure of $1^{\text {st }}, 2^{\text {nd }}$ SHG girl students of pedagogic HEE

\begin{tabular}{|c|c|c|c|c|c|}
\hline № & Description of activities & $\begin{array}{l}\text { Constantly and } \\
\text { regularly, \% }\end{array}$ & $\begin{array}{l}\text { Often, } \\
\%\end{array}$ & $\begin{array}{l}\text { From time to } \\
\text { time, \% }\end{array}$ & $\begin{array}{l}\text { Practically no } \\
\text { activities, \% }\end{array}$ \\
\hline 1. & Listening to audio records & 34,6 & 44,2 & 21,2 & 0 \\
\hline 2. & Watching TV, video & 16,4 & 37,5 & 34,6 & 11,5 \\
\hline 3. & Reading of newspapers, magazines & 13,5 & 31,7 & 39,4 & 15,4 \\
\hline 4. & Reading of fiction & 39,4 & 34,6 & 23,1 & 2,9 \\
\hline 5. & Participation in social life & 16,3 & 28,0 & 41,3 & 14,4 \\
\hline 6. & Physical culture, hiking & 18,3 & 10,6 & 36,5 & 34,6 \\
\hline 7. & Attending of disco & 6,7 & 25,0 & 32,7 & 35,6 \\
\hline 8. & $\begin{array}{l}\text { Attending of theatres, exhibitions, } \\
\text { museums }\end{array}$ & 7,7 & 11,5 & 53,8 & 27,0 \\
\hline 9. & Meeting with friends & 11,5 & 79,8 & 8,7 & 0 \\
\hline 10. & Attending of sport shows, competitions & 2,0 & 11,5 & 30,7 & 55,8 \\
\hline 11. & $\begin{array}{l}\text { Collecting, photographing, cinema } \\
\text { shooting }\end{array}$ & 3,8 & 13,4 & 30,0 & 52,8 \\
\hline 12. & $\begin{array}{l}\text { Study of special literature, participation } \\
\text { in scientific work }\end{array}$ & 34,6 & 25,0 & 36,5 & 3,9 \\
\hline 13. & Playing cards, domino, etc. & 2,0 & 22,1 & 35,6 & 40,3 \\
\hline 14. & Playing music, writing poems, painting & 15,4 & 18,3 & 26,0 & 40,3 \\
\hline 15. & Visiting restaurants, café, bars & 2,0 & 22,1 & 35,6 & 40,3 \\
\hline 16. & Amateur art & 4,8 & 11,5 & 42,3 & 41,4 \\
\hline 17. & Technical constructing, rationalization & 0 & 8,7 & 22,1 & 69,2 \\
\hline 18. & Handicraft, needlework & 2,0 & 6,7 & 33,7 & 57,6 \\
\hline
\end{tabular}

Table 2. Day regime of SHG girl students of pedagogic HEE

\begin{tabular}{|c|c|c|c|}
\hline № & Questions & Answers (\%) & Day off \\
\hline \multirow[t]{10}{*}{1} & At what time do you awake? & & \\
\hline & 6 a.m. & 5,2 & \\
\hline & 7.30 a.m. & 31,7 & \\
\hline & 8 a.m. & & 4.8 \\
\hline & 7.00 a.m. & 63,1 & 8.6 \\
\hline & 9 a.m. & & 8.6 \\
\hline & 10 a.m. & & 28,0 \\
\hline & 11 a.m. & & 18,2 \\
\hline & 12 a.m. & & 27,0 \\
\hline & Late & & 4.8 \\
\hline \multirow[t]{3}{*}{2} & Do you do morning exercises? & & \\
\hline & Every day & 36,4 & 35,6 \\
\hline & Never & 63,6 & 64,4 \\
\hline \multirow[t]{4}{*}{3} & How much time your way to HEE takes? & & \\
\hline & $60 \mathrm{~min}$. & 50 & \\
\hline & $90 \mathrm{~min}$. & 38,4 & \\
\hline & $15-20 \min$. & 11,6 & \\
\hline \multirow[t]{3}{*}{4} & Do you have breakfast at home? & & \\
\hline & I have breakfast at home & 30,1 & 71,2 \\
\hline & I do not have breakfast at home & 69,9 & 28,8 \\
\hline \multirow[t]{3}{*}{5} & Do you have breakfast at HEE & & \\
\hline & I have breakfast at HEE & 54,6 & \\
\hline & I do not have breakfast at HEE & 45,4 & \\
\hline \multirow[t]{3}{*}{6} & Do you have lunch? & & \\
\hline & Yes & 91,0 & 100 \\
\hline & No & 9,0 & \\
\hline \multirow[t]{3}{*}{7} & Do you need afternoon meal? & & \\
\hline & Yes & 22,7 & 10,6 \\
\hline & No & 77,3 & 89,4 \\
\hline \multirow[t]{3}{*}{8} & Do you have supper? & & \\
\hline & Yes & 86,4 & 91,4 \\
\hline & No & 13,6 & 8,6 \\
\hline \multirow[t]{3}{*}{9} & What is your eating? & & \\
\hline & Adequate & 49,6 & 48,9 \\
\hline & Hearty & 50,4 & 51,1 \\
\hline \multirow[t]{2}{*}{10} & How much time is taken by home tasks? & & \\
\hline & 1 hour (60 min.) & 30,4 & 26,9 \\
\hline
\end{tabular}


Table 2 (continued)

\begin{tabular}{|c|c|c|c|}
\hline 1 & 2 & & 4 \\
\hline \multirow{8}{*}{11} & 2 hours & 41,3 & 37,5 \\
\hline & 3 hours & 13,6 & 22,1 \\
\hline & 4 hours & 9,0 & 2,0 \\
\hline & I do not do home tasks & 5,7 & 11,5 \\
\hline & How much time is taken by your hobby, leisure in day? & & \\
\hline & 1 hour (60 min.) & 35,5 & 5,8 \\
\hline & 2 hours & 46,2 & 25,0 \\
\hline & 3 hours & 9,6 & 28,8 \\
\hline \multirow{3}{*}{12} & 4 hours & 8,7 & 40,4 \\
\hline & At what time do you go to bed? & & \\
\hline & 23 hours & 40,9 & 38,5 \\
\hline \multirow{5}{*}{13} & 24 hours & 45,4 & 46,1 \\
\hline & Later & 13,7 & 15,4 \\
\hline & Do you walk before sleep? & & \\
\hline & Yes & 42,3 & 69,2 \\
\hline & No & 57,7 & 30,8 \\
\hline
\end{tabular}

Creative activity (play music, poetry, painting) engages only $15.4 \%$ of girl students; 53.8 girl students attend theatres from time to time. $7.7 \%$ of girl students attend museums and exhibitions and $423 \%$ participate in amateur art from time to time.

The second questionnaire was devoted to girl students' day regime. Correctly organized day regime is a compulsory condition of successful life activity. Rational regime of work and rest shall be an ABC of girl students' life activity. Girl students shall observe all components of day regime: morning exercises, morning toilet, home tasks' fulfillment, being in the fresh air, leisure activities, moderate attending of different shows, evening meal, evening walk and preparing for sleep.

However, the questioning showed the following (see table 2). Om weekdays most of girl students (63.1\%) awake at 7.00 a.m. $31.7 \%$ girl students start their day at 7.30 and $5.2 \%$ - at 6 a.m. $36.4 \%$ do morning exercises. This fact witnesses that girl students are not interested in health strengthening and preservation.

In $50 \%$ of girl students the way to the place of studying takes about one hour. $38.4 \%$ spend about one and half hour to get to HEE. The rest of girl students get to HEE for 15-30 minutes. It is quite clear that time and energy losses, connected with going to HEE aggravate the health of most of girl students.

For normal life activity of SHG girl students it is necessary to observe eating regime, which implies its frequency rate during day; definite intervals between taking food. When organizing eating, it is necessary to consider energy value and quantitative correlation of food main components. Questioning results showed that 20.1\% of girl students do not have breakfast. Lunch (at HEE) is practiced (after first academic pair) only by $13.6 \%$ girl students. After second academic pair $41 \%$ have meal. $45.4 \%$ of girl students do not have meal at HEE at all. The questioning also showed that $91 \%$ of girl students have dinner at home within $14.00-17.00$ p.m. $9 \%$ of girl students do not have dinner at all. $77.3 \%$ of girl students do not need afternoon meal. $86.4 \%$ have supper and $13,6 \%$ of respondents do not have supper at all. The question "What is your eating? (adequate, hearty) was answered: $49.6 \%$ have adequate eating; $50.4 \%$ have hearty eating. At first sight there is no danger in these answers. However, in some cases it creates discomfort in academic activity and is dangerous for health. It is connected with the fact that mental, physical and etc. human activity is realized at the account of metabolism in organism.

As a result of our research we found time expenditures for home tasks' fulfillment and for leisure activities. Most of girl students $(41.3 \%)$ do home tasks during two hours a day. 5.7\% do not do home tasks at all. $12 \%$ (from those, who do home tasks) spend one hour for it. Only $9 \%$ do home tasks during 4 hours a day. 18.4\% spend 1 hour a day for doing home tasks and $13.6 \%$ spend 3 hours for this work.

Information about leisure time is also interesting. Most of SHG girl students (46.2\%) spend for leisure (hobby) 2 hours a day and 35\% - not more than 1 hour. 9.6\% spend 3 hours and $8.7 \%-4$ hours a day.

Results of our studies show that after intensive working day girl students especially need in adequate sleep to ensure full fledged rest for organism. Physiological demand in sleep duration of girl students with health problems is 8 hours a day. We found that $40.9 \%$ of girl students go to bed at 22.00-23.00 p.m.; 45.4 - at midnight; $13.7 \%$ of girl students go to bed much later. Shortening of sleep duration is a violation of sleep regime.

Results of our studies show that this research permits to start qualitatively new process of organization of individual, health related applied work with girl students. For example, we cleared up organization of girl students' life activity in day off. In day off $22 \%$ of girl students get up: $8.6 \%$ - at 7 a.m.; $4.8 \%$ - at 8 a.m. and $8.6 \%$ - at 9 a.m. Most of girl students (28\%) awake at 10 a.m.; 18.2\% - at 11 a.m.; $27 \%$ - at noon and $4.8 \%$ - at 1 p.m. It is known that excessive sleep facilitates progressing of phlegm, disorders many vitally important functions of organism. Only $35.6 \%$ of girl students do morning exercises at day off (by $0.8 \%$ less than on weekdays). $2 \%$ of girl students do not have breakfast on day off. All 300 girl students have dinner but in different time. $8.6 \%$ do not have 
meal before sleep. Household affairs (helping parents, tiding of flat and so on) take 3 hours a day in $31.9 \%$ of girl students. $13 \%$ spend 1 hour a day for home affairs. Home tasks' fulfillment in day off takes: 4 hours - in 2\% of girl students; 3 hours - in $22.1 \%$. Most of girl students $(37.5 \%)$ spend 2 hours of free time for doing home tasks. $26.9 \%$ spend 1 hour for this work and $11.5 \%$ do not do home tasks at all.

\section{Discussion}

Studying of this topic is conditioned by the fact that works of many authors are directed at formation of the following features in students: proper attitude to own health [15, 16, 29]; long-term support of healthy life style [17, 22]; individual health related applied activity of girl students [2].

Practically every girl student has many obligations and affairs. Sometimes girl student feels deficit of time. As a result, solving little problems, girl student forgets about priorities of health values. She sleeps a little, does not run in the morning, does not practice hiking, takes meal, reading book and so on. For recreation of workability and health strengthening girl students shall have active leisure; be in the fresh air as much as possible; practice physical exercises. In this case the authors of this article do not agree with foreign specialists, who exaggerate the danger of excessive weight [23] and progressing of global obesity [25] in most of adolescents with insufficient motor activity [11] and young people [24]. By results of our researches, youth is not completely physically inactive. Youth reasonably organizes leisure and individual life style in higher educational establishment [2].

Results of our research shows that this research permits to start qualitatively new process of organization of individual, health related applied work with girl students. It complies with studies of other authors, devoted to physical culture health related work with girl students [13], to propaganda of active Judo trainings, which are interesting for students $[9,10]$.

The authors prove that after intensive working day girl students especially need in adequate sleep to ensure full fledged rest for organism. Here, certain pedagogic control over motor activity of senior school age girls is required. In the future, such control will help to girls to correctly understand physical education and correct life style values $[8,12]$.

As a result of our research we found time expenditures for home tasks' fulfillment and for leisure activities.
Diagnostic procedure on initial stage included questioning of SHG girl students about their life activity and attitude to health related applied activities. These indicators are important elements of motivation mechanism of girl students' health related applied education, which is required for working out and realization of adequate pedagogic provisioning of the tested process. Analysis of questionnaires showed that most of students have positive attitude to healthy life style. It is in agreement with other works [1, 10, 21]. About one/third of girls students have negative attitude to healthy life style. As reasons, they named internal factors: absence of demand, will power; absence of appropriate emotional background; presence of harmful habits and external factors: students' life conditions do not permit, inconvenient time table, great academic load, uncertainty in the future and so on.

Simultaneously we studied special leisure activities. This sphere implies individual preferences and interests, selection of values. The character of leisure is a necessary condition of physical condition's development and health strengthening; participation in social life and cultural progress of personality. Such day regime influences on girl students' health and way of life. This problem was solved also by other specialists [29]. They studied interconnections of morphological, functional indicators of students and fulfilled comparative research of exercises' influence on students' physical and psychic health [30] and their functional potentials [14].

Organized talks with girl students after questioning and analysis of its results permitted to make other positive conclusions. Our results show that girl students, nevertheless, have moderate demand in individual health related applied activity. One of reasons of it is that sport clubs and other public sport-health related organizations do not involve girl students in their practices. There is discussible contradictory state motivation demand in individual health related applied activity of girl students.

\section{Conclusions}

Thus, social-pedagogic analysis of SHG girl students of pedagogic HEE showed the following:

- In free time girl students attach great importance to activities, which are not connected with physical culture.

- There is moderate state motivation demand in individual health related applied activity of SHG girl students.

\section{Conflict of interests}

The authors declare that there is no conflict of interests. 


\section{References}

1. Adyrkhaev SG. Modern technology of physical education of disabled students in conditions of inclusive education. Pedagogics, psychology, medical-biological problems of physical training and sports, 2016; 20(1): 4-12. doi:10.15561/18189172.2016.0101

2. Bartnovskay LA, Kudryavtsev MD, Iermakov SS, Kravchenko VM, Osipov AYu, Kramida IE. Health related applied technology of special health group girl students' physical training. Physical education of students, 2017;1:49.doi:10.15561/20755279.2017.0101

3. Bliznevsky AA, Kudryavtsev MD, Iermakov SS, Jagiello W. Formation of active-effective attitude of 12-13 years' judo athletes to sports functioning in competition period. Archives of Budo. 2016;12:101-15.

4. Chen H, Dai J, Gao Y. Measurement invariance and latent mean differences of the chinese version physical activity self efficacy scale across gender and education levels. Journal of Sport and Health Science [Internet]. 2017 Jan [cited 2017 Jan 11]; Available from: http://linkinghub.elsevier.com/retrieve/ pii/S209525461730004

5. Crahay, M. Dangers, uncertainties and incompleteness of the logic of competence in education. Revue française de pédagogie, 2006; 154: 97-110 p.

6. Erman KA, Şahan A, Balci YK. The Vocational Maturity of School of Physical Education and Sports Students. Procedia - Social and Behavioral Sciences. 2015;174:2380-3.

7. Gaskov AV, Kuzmin VA, Kudryavtsev DM, Iermakov SS. Successfulness of general and special physical qualities' development on different stage of students-boxers' training. Physical Education of Students. 2016;20(1):4-11. doi:10.15561/20755279.2016.0101

8. Gråstén A. Children's expectancy beliefs and subjective task values through two years of school-based program and associated links to physical education enjoyment and physical activity. Journal of Sport and Health Science. 2016;5(4):500-8.

9. Iermakov SS, Arziutov GN, Jagiello W. Quick training of students to judo techniques. Archives of Budo. 2016;12:1524.

10.Iermakov SS, Podrigalo LV, Jagiello W. Hand-grip strength as an indicator for predicting the success in martial arts athletes. Archives of Budo. 2016;12:179-86.

11.Ivashchenko OV, Kapkan OO. Informative pedagogic control indicators of 14-15 years age girls' motor fitness. Pedagogics, psychology, medical-biological problems of physical training and sports, 2016; 20(6): 18-25. doi:10.15561/18189172.2016.0603

12.Ivashchenko OV. Methodic of pedagogic control of 1617 years' age girls' motor fitness. Pedagogics, psychology, medical-biological problems of physical training and sports, 2016; 20(5): 26-32. doi:10.15561/18189172.2016.0504

13.Kondakov V.L., Kopeikina E.N., Usatov A.N., On purposefulness of application of physical culture-health related technology for prophylaxis of students' respiratory system disorders. Physical Education of Students, 2016;20(2):4-12. doi:10.15561/20755279.2016.0201

14.Kopeikina E.N., Drogomeretsky V.V., Kondakov V.L., Kovaleva M.V., Iermakov S.S., Modification of Harvard step-test for assessment of students' with health problems functional potentials. Physical Education of Students, 2016;4:44-50. doi:10.15561/20755279.2016.0405

15.Kopylov Yu.A., Jackowska L.N., Kudryavtsev M.D., Kuzmin V.A., Tolstopyatov I.A., Iermakov S. S., The concept of structure and content of health related trainings for higher educational establishments' students. Physical Education of Students, 2015;5:23-30.doi:10.15561/20755279.2015.0504

16.Kozina Z.L., Iermakov S.S., Kadutskaya L.A., Sobyanin F.I., Krzeminski M., Sobko I. N., Ryepko O.A., Comparative characteristic of correlation between pulse subjective indicators of girl students' and school girls' reaction to physical load. Physical Education of Students, 2016;4:2434. doi:10.15561/20755279.2016.0403

17.Kudryavtsev M.D., Kopylov Yu.A., Kuzmin V.A., Ionova O.M., Yermakova T.S., Personality oriented system of strengthening of students' physical, psychic and socialmoral health. Physical Education of Students, 2016;3:58-64. doi:10.15561/20755279.2016.0308

18.Kudryavtsev M.D., Kramida I.E., Iermakov S.S., Influence of studying in higher educational establishment on students' harmful computer habits. Physical Education of Students, 2016;5:17-23. doi:10.15561/20755279.2016.0503

19.Kudryavtsev M.D., Kramida I.E., Iermakov S.S., Osipov A.Yu., Development dynamic of healthy life style personality component in relatively healthy students. Physical Education of Students, 2016;6:26-33. doi:10.15561/20755279.2016.0603

20.Kudryavtsev M.D., Kramida I.E., Kuzmin V.A., Iermakov S.S., Cieslicka Miroslawa, Stankiewicz Blazej, Influence of study in hee on ubiquity and strength of students' computer gambling. Physical Education of Students, 2016;3:13-22. doi:10.15561/20755279.2016.0302

21.Kuzmin V. A., Kopylov Y. A., Kudryavtsev M. D., Tolstopyatov I. A., Galimov G. Y., Ionova O. M. Formation of professionally important qualities of students with weakened motor fitness using a health related and sport-oriented training program. Journal of Physical Education and Sport, 2016;16(1):136-145. doi:10.7752/jpes.2016.01023

22.Kuzmin V.A., Kopylov Yu.A., Kudryavtsev M.D., Galimov G.Y., Iermakov S. S., Substantiation of effectiveness of trainings on health related methodic for students with weakened motor fitness. Physical Education of Students, 2015;6:43-49. doi:10.15561/20755279.2015.0606

23.Lindström M, Isacsson SO, Merlo J. Increasing prevalence of overweight, obesity and physical inactivity: two populationbased studies 1986 and 1994. Eur J Public Health. 2003;13(4):306 - 12 .

24.Marchenko OYu. Gender piculiarities and distinctions in physical condition's self description of different age categories girls and boys. Pedagogics, psychology, medicalbiological problems of physical training and sports, 2016; 20(1): 24-33. doi:10.15561/18189172.2016.0104

25.Obesity: preventing and managing the global epidemic: Report of a WHO consultation. - Technical report series 894. - Geneva: WHO; 2000.

26.Osipov A.Yu., Kudryavtsev M.D., Kramida I.E., Iermakov S.S., Kuzmin V.A., Sidorov L.K. Modern methodic of power cardio training in students' physical education. Physical Education of Students, 2016;6:34-39. doi:10.15561/20755279.2016.0604

27.Osipov AYu, Kudryavtsev MD, Gruzinky VI, Kramida IE, Iermakov SS. Means of optimal body mass control and obesity prophylaxis among students. Physical education of students, 2017;1:40-45. doi:10.15561/20755279.2017.0107

28.Pang B, Soong H. Teachers' experiences in teaching Chinese Australian students in health and physical education. Teaching and Teacher Education. 2016;;56:84-93.

29.Podrigalo LV, Iermakov SS, Alekseev AF, Rovnaya OA. Studying of interconnections of morphological functional indicators of students, who practice martial arts. Physical Education of Students. 2016;20(1):64-70. 
30.Skead NK, Rogers SL. Running to well-being: A comparative study on the impact of exercise on the physical and mental health of law and psychology students. International Journal of Law and Psychiatry. 2016;49:66-74.
31.Skurikhina N.V., Kudryavtsev M.D., Kuzmin V.A., Iermakov S.S. Fitness yoga as modern technology of special health groups' girl students' psycho-physical condition and psychosocial health strengthening. Physical Education of Students, 2016;20(2):24-31. doi:10.15561/20755279.2016.0204

\section{Information about the authors:}

Bartnovskay L.A.; http://orcid.org/0000-0003-0480-2257; larabart@mail.ru; Krasnoyarsk State Pedagogical University named after V.P. Astafyev; Ady Lebedevoy Street, 89, Krasnoyarsk, 660049, Russia.

Kudryavtsev M.D.; http://orcid.org/0000-0002-2432-1699; kumid@yandex.ru; Siberian Federal University; 79 Svobodny pr., Krasnoyarsk, 660041, Russia.; Reshetnev Siberian State University of Science and Technology; Office A-406, 31, Krasnoyarsky Rabochy Av., 660014, Krasnoyarsk, Russia.; Krasnoyarsk State Pedagogical University named after V.P. Astafiev; Ada Lebedeva Street, 89, Krasnoyarsk, 660049, Russia.; The Siberian Law Institute of the Ministry of Internal Affair of Russia; Rokossovskia str., 20, Krasnoyarsk, 660131, Russia.

Kravchenko V.M.; http://orcid.org/0000-0002-7227-9296; ver1113@yandex.ru; Krasnoyarsk State Pedagogical University named after V.P. Astafyev; Ady Lebedevoy Street, 89, Krasnoyarsk, 660049, Russia.

Osipov A.Yu.; http://orcid.org/0000-0002-2277-4467; Ale44132272@ya.ru; Siberian Federal University; 79 Svobodny pr., Krasnoyarsk, 660041, Russia.; Professor V.F. Voino-Yasenetsky Krasnoyarsk State Medical University; P. Zeleznyak, 1, Krasnoyarsk, 660022, Russia.

Baranovskaya L.A.; http://orcid.org/0000-0003-2470-1613; inlangkaf@gmail.com; Reshetnev Siberian State University of Science and Technology; Office A-406, 31, Krasnoyarsky Rabochy Av., 660014, Krasnoyarsk, Russia.

Ignatova V.V.; http://orcid.org/0000-0003-3382-3348; valyaig@mail.ru; Reshetnev Siberian State University of Science and Technology; Office A-406, 31, Krasnoyarsky Rabochy Av., 660014, Krasnoyarsk, Russia.

Cite this article as: Bartnovskay LA, Kudryavtsev MD, Kravchenko VM, Osipov AYu, Baranovskaya LA, Ignatova VV. Individual health related applied activity in special health group girl-students' way of life in the process of their studying.. Pedagogics, psychology, medical-biological problems of physical training and sports, 2017;21(5):207-213. doi:10.15561/18189172.2017.0502

The electronic version of this article is the complete one and can be found online at: http://www.sportpedagogy.org.ua/index.php/PPS/issue/archive

This is an Open Access article distributed under the terms of the Creative Commons Attribution License, which permits unrestricted use, distribution, and reproduction in any medium, provided the original work is properly cited (http://creativecommons.org/licenses/by/4.0/deed.en).

Received: 06.04.2017

Accepted: 25.04.2017; Published: 25.09.2017 